\title{
B17 サッカースパイクソール設計のための基礎研究
}

Basic research on sole design in soccer boots

○松尾弘毅（アシックス スポーツ工学研）, 森安健太, 正 西脇剛史

Koki MATSUO,Kenta MORIYASU, and Tsuyoshi NISHIWAKI

ASICS Corporation, 6-2-1, Takatsukadai, Nishi-ku, Kobe

\begin{abstract}
Traction between footwear and surface is crucial to improving performance and preventing lower limb injuries. In field sports such as soccer, the cleats penetrate and interlock with the playing surface. The purpose of this study is to obtain elementary information for sole designing in soccer boots. Soccer boot traction depends on cleat geometry and arrangement. The proposed technique with miniature sensors measures ground reaction force (GRF) distribution. By using test boots with 16 cleats and miniature sensors, the force components loaded on each cleat are measured in the side step motion. Length of step are $70,90,110 \mathrm{~cm}$. GRF distributions are also measured using boots with different cleat arrangements. The effects of cleat arrangement on GRF distributions are quantitatively evaluated.
\end{abstract}

Key Words: foot ball, soccer, soccer boots, cleats, traction, grip property

\section{1. 粕言}

近年, サッカースパイクへの要求機能として, ブレ 球に代表されるボールの操作性や，軽量性に注目が集 まりがちであるが，サッカースパイクを設計する上で 最も重要とされる機能として，グリップ性が挙げられ る.このグリップ性は, シューズ底面に取り付けられ たクリーツと呼ばれる突起物を，芝に貫入させること で発現される．これまで，サッカースパイクのクリー ツ形状がシューズのグリップ性に及ぼす影響は，いく つか報告されており，パフォーマンスに関しては，グ リップ性の向上による走速度の上昇が指摘されている 1). その一方で, グリップ性の向上は, 関節への負担が 増大するという報告 ${ }^{2)}$ もるため，グリップ性を考慮 したサッカースパイクのクリーツ設計は，パフォーマ ンス向上及び障害予防の両側面からも重要といえる.
シューズのグリップ性は，通常フォースプレートで測 定された接地面全体の水平方向荷重や，水平方向荷重 を鉛直方向荷重で除することで得られるトラクション 係数などにより評価されている.しかし，この評価手 法では,接地エリア全体にかかる荷重を用いることに なり,クリーツの最適配置や最適形状をより詳細に検 討するためには，クリーツ単体に作用する 3 次元的な 荷重情報の取得が望ましい。

3 次元的な荷重情報の取得に関しては, ゴルフシュ 一ズのクリーツにひずみゲージを貼付し測定した報告 がある ${ }^{3)}$. しかし，歪ゲージをクリーツに直接貼付す るため，実験準備に多くの時間を要する上に，ゲージ の出力之地面反力を直接関連づける事は, 困難である. 筆者らはこれまでに,小型 3 軸力覚センサを搭載したシ ューズを開発し,ランニング動作中の接地エリア内の 3

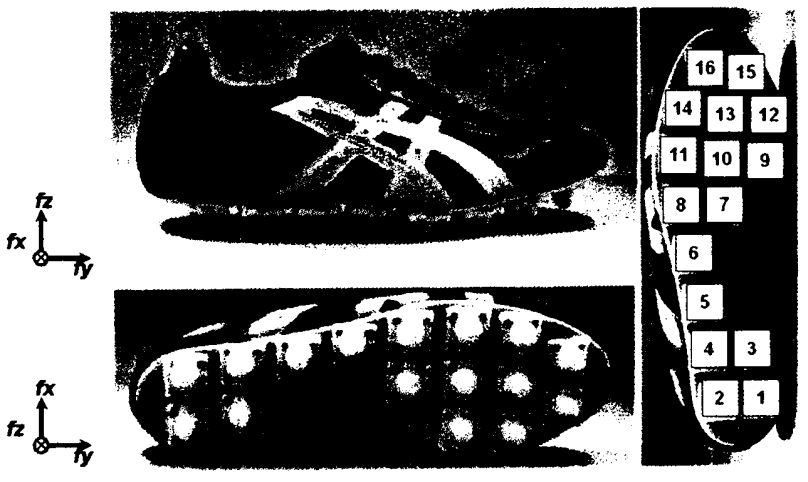

(a) Sensor boot

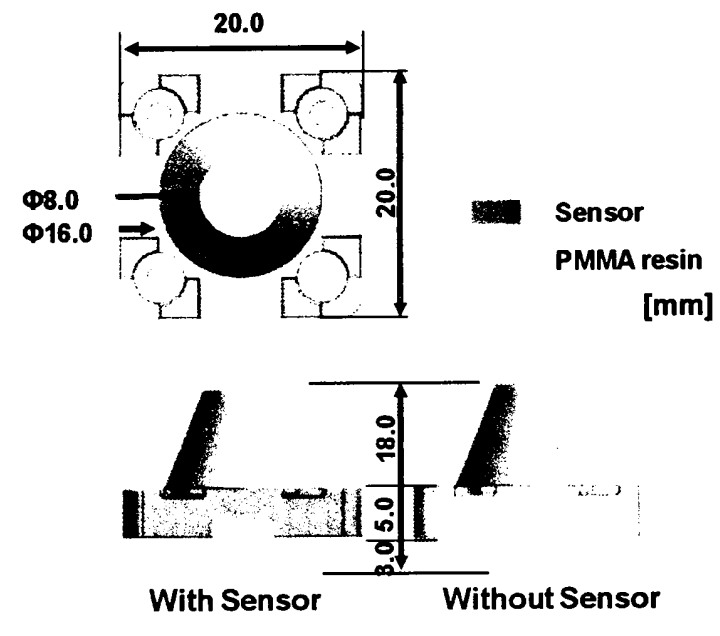

(b) Geometry of cleats with sensor

Fig. 1 Sensor boot construction used in evaluation

日本機械学会［No.11-17] シンポジウム:スポーツ・アンド・ヒューマン・ダイナミクス 2011 講演論文集〔'11-10.31〜11.2, 京都] 
方向荷重分布について報告している ${ }^{4), 5)}$ ．また，既報に おいて, サイドステップ時の接地エリア内の荷重分布 測定を行い，グリップ性に影響を及ぼすエリアが前足 部内側, 特に拇趾球近傍であることを確認した. また， クリーツの有無にともなう近接クリーツの影響につい ても定量的に確認した.

本報告では，サイドステップにおけるステップ幅を 変化させた際の, 地面反力, 及び接地エリア内の荷重 分布を明らかにした. 更にクリーツ高さを変化させる ことで，局所的にグリップ性を変化させた際の，近接 するクリーツへの影響をステップ幅変化と共に議論し た.

\section{2. 横方向ステップ動作実験}

\section{2-1 センサシュース}

Fig.1 に開発したサッカースパイクをクリーツ形状 と共に示す.サッカースパイクの底面には， 5 個の小 型 3 軸力覚センサ(USL06-H5, テック技販社製, サイ ズ : $20 \mathrm{~mm} \times 20 \mathrm{~mm} \times 5.0 \mathrm{~mm}$ )が同時に取り付け可能であ り，センサ位置を変化させることで，クリーツ毎に作 用する荷重が取得できる. 小型 3 軸力覚センサは, 出 力される荷重 $\mathrm{fx}$, fy 及び $\mathrm{fz}$ がそれぞれシューズの足幅, 足長及び鉛直方向に対応するように配置した。使用し たセンサ配置を Tablel に示す。センサの位置番号 i=1-16 は, ソール底面画像内に示寸番号に対応してお り, 本実験では 4 タイプのセンサ配置にて測定を実施 することで, 計 16 箇所のクリーツに作用する 3 方向荷 重分布を算出した. 尚, 爪先部内側のセンサ $i=15$ は動 作の再現性確認のため全試技にて配置した. センサが 配置されていないエリアには，センサ取り付け部との 高さを保持させるために 3 次元造形機 Objet(Objet 社製) を用いてセンサと同一形状を有する PMMA 製のダミ 一を作製し，配置した。 センサ部は $3 \mathrm{~mm}$ 厚の PMMA 板, 力覚センサ並びに円柱状のクリーツ部 (上面 $\phi 8 \mathrm{~mm}$, 下面 $\phi 16 \mathrm{~mm}$, 高さ $10 \mathrm{~mm}$ ) で構成される. シューズ重 量は, $258.8 \mathrm{~g}$ である.

Tablel Sensor configurations

\begin{tabular}{|c|c|c|}
\hline$\frac{15 \sqrt{6}}{12 \sqrt{14}}$ & & Sensors' position numbers \\
\hline 900 & Type1 & $i=1,2,3,4,15$ \\
\hline (1) & Type2 & $i=5,6,7,8,15$ \\
\hline 5 & Type3 & $i=9,11,13,15,16$ \\
\hline (1) & Type4 & $i=10,12,14,15,16$ \\
\hline
\end{tabular}

\section{2-2実験方法}

開発したスパイクを用い，人工芝上でのサイドステ ップ動作を行い，16 箇所のクリーツに作用する 3 方向 荷重分布を測定した．ステップ幅は, $70 \mathrm{~cm}, 90 \mathrm{~cm}, 110 \mathrm{~cm}$ とした。試技は，メトロノームにて $50 \mathrm{bpm}$ を指示する ことで，一定のリズムで害施した．本実験では， 3 方 向荷重分布測定と同時に, 汎用のフォースプレート (9287C, Kistler 社製)を用いて接地面全体の地面反力も 測定した. 使用した力覚センサ及びフォースプレート のサンプリング周波数はいずれも $1.0 \mathrm{KHz}$ とした.

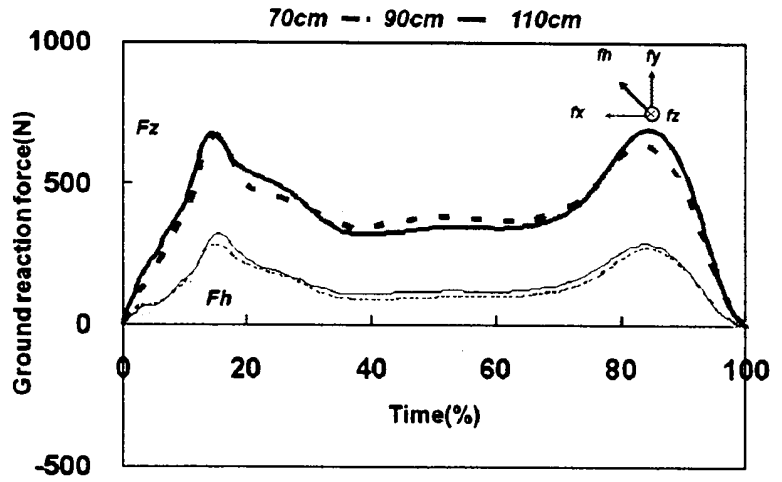

Fig.2 The whole GRF obtained from side step motion

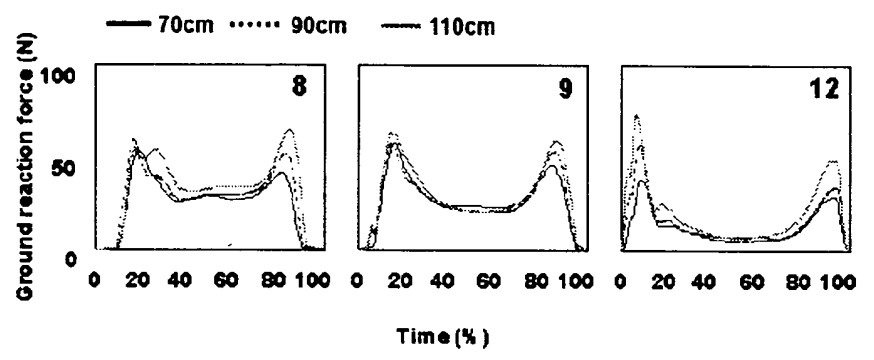

Fig.3 Time histories of local horizontal GRF obtained from force sensor at $i=8,9$ and 12
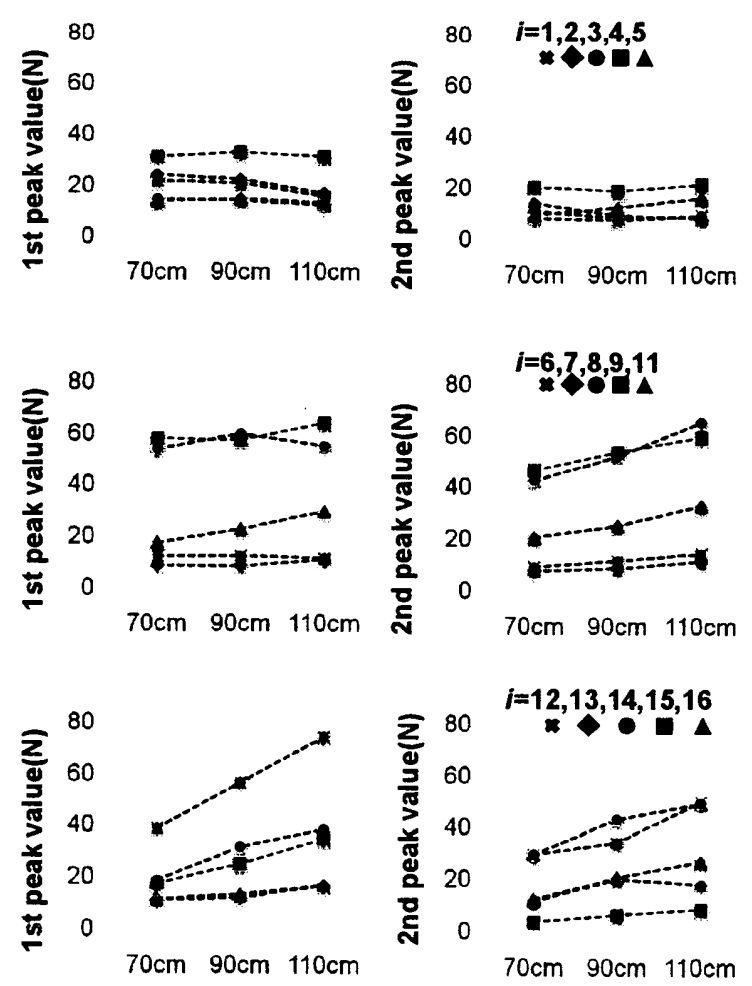

(a) lst peak

(b) 2nd peak

Fig.4 Comparison of peak value 


\section{2-3 実験結果}

Fig.2に, ステップ幅を変化させた際のサイドステッ プ動作時におけるフォースプレートより得られた地面 反力の時系列変化を示す. Fig.2 中の太線は鉛直方向反 力 $F z$, 細線は水平方向反力 $F h$ を表す. $F h$ は, Eqn. 1 で定義した。

$$
F h=\sqrt{f x^{2}+f y^{2}} \text { (Eqn.1) }
$$

ここで,Fhは，フォースプレートの Fx 及び Fy 成分の 合力を意味する. 全ての試技において, 接地後と離地 直前にピークが見られた. Fhにおいては，ステップ幅 が増加するに従って，1stピーク值，2nd ピーク值なら びに支持期全体の力積值共に，増加することを確認し た. 一方, 鉛直方向反力のピーク值及び力積值は, 僅 かに増加する程度であった。これは，ステップ幅の増 加に従い，体勢を維持するためにより大きなグリップ 力が必要になったためであると推察される.

Fig.3 に $i=8,9 ， 12$ に位置するクリーツより得られた 水平方向荷重成分 $f h i$ の時系列変化を示す. Fig. 3 によ れば, サイドステップ動作においては, クリーツ単体 に作用する荷重の変化は, Fig.2のフォースプレートよ り得られた地面反力の時系列変化と同様に, 二峰性の ピークを有することが分かる. 本結果は, 全てのクリ 一ツ位置において同様の傾向を示すことが確認された. Fig.4 に各クリーツに作用する水平方向荷重のピーク 值とステップ幅の関係を示す. Fig.4 (a), (b)はそれぞれ 1st ピーク值, 2nd ピーク值を示す. ステップ幅の増加 に対する水平方向荷重変化を比較した結果, 1st ピーク 値, 2nd ピーク值ともに踵部に位置する $i=1,2,3,4,5$ のク
リーツは，ピーク値が減少していることが分かる。一 方, 中足部, 前足部に位置する $i=9,11,12,15,16$ クリー ツは, いずれのピーク值も, 増加傾向を示した. 特に $\mathrm{i}=9,12$ において増加率は顕著であることが確認できた.

\section{3. クリーツ形状と地面反力の関係}

前章において地面反力及び 3 方向荷重分布を基に, サイドステップ動作の接地エリアの変化を明らかにし， グリップ性に影響の大きいクリーツエリアを抽出した. 次に, 抽出したクリーツの高さ変化が, 周辺のクリー ツに作用する荷重に与える影響を検討する。

\section{3-1 実験方法}

シューズのクリーツ高を変化させるために, Fig5.に 示すように，上面と下面のサイズが一定で，高さのみ を変化させたクリーツをPMMAにて作製した. 取り付 け条件は, 全面が $10 \mathrm{~mm}$ のクリーツ高で構成された TypeA に対し, TypeB，Cには，それぞれ $i=9, i=12 に$ のみ高さ $5 \mathrm{~mm}$ のクリーツを配し,クリーツ高を変化さ せた。実験は，前章と同一の手法で実施し，ステップ 幅 $90 \mathrm{~cm}$ における, 荷重分布及び地面反力を測定した.

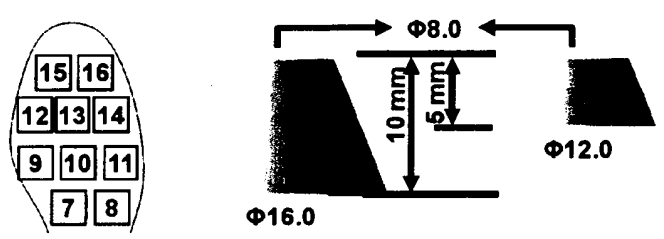

Fig.5 Cleats types of shape

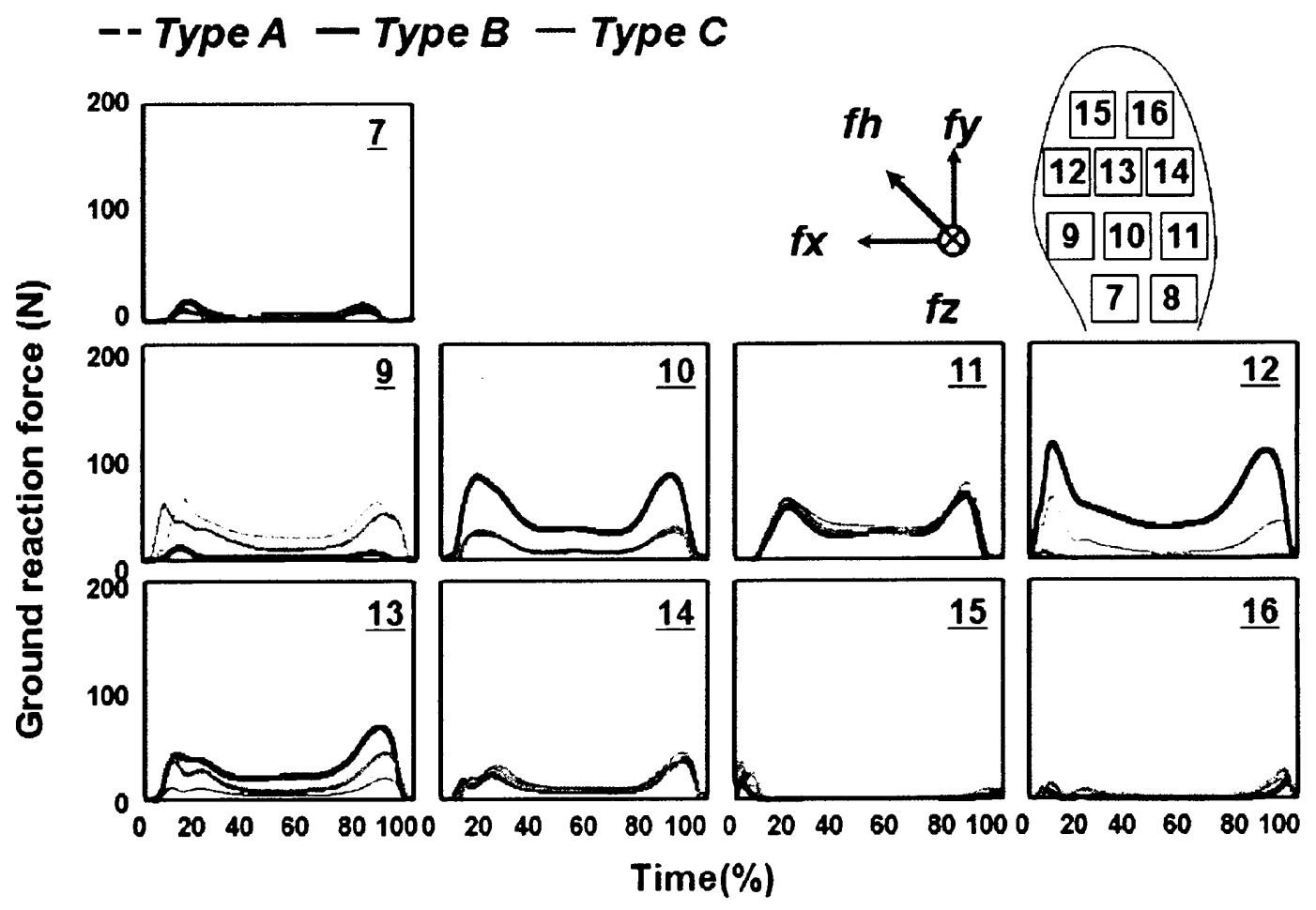

Fig.6 Time histories of Horizontal ground reaction force obtained from force sensor 


\section{3-2 水平方向地面反力分布に与える影䈉の検証}

クリーツ高を部分的に変化された 3 タイプのシュー ズより得られた水平方向荷重成分の時系列変化を Fig.6に示す. Fig.6によれば, TypeB 及びCのいずれ においても,クリーツ高が低い $i=9,12$ の接地圧が减少 し，出力值が低くなることが確認できる。 また，それ に伴い，他のクリーツに作用する水平方向荷重の挙動 及びピーク值に差異が生じることが分かる.

クリーツに作用する水平方向荷重を比較した結果,

TypeB の $i=10$ において, ピーク值が TypeA に比べ約 3.3 倍, TypeC に比べ約 2.9 倍増加することが分かった。 TypeC においては $i=9$ において TypeAに比べピーク值 の出現時間が約 5.4 割早くなることが分かった。この ように, クリーツ高さの局所的な堿少は, 周囲のクリ 一ツに対して，負荷が増大することや，接地のタイミ ングを早めるといった影響を与える事が分かった.

そこで, シューズに対するクリーツの荷重負担関倸 を検討すべく, クリーツ $i(i=7-16)$ に作用する水平方向 荷重の力積 $\Sigma f h i$ を比較した.

Fig.7に, Type A,B,Cより得られた $\Sigma f h i$ を示す. TypeA と TypeB を比較すると, 各クリーツの力積の関係が大 きく異なる. 特に, クリーツ高を低下させた $i=9$ 周辺 $(i=10,12,13)$ の值が增大していることが分かる. その 一方で, $i=11$ は, TypeAに比べ減少していることから, $i=9$ のクリーツ高の低下により, シューズと路面の接地 状態が変化し, 前足部内足側の広範囲で水平方向荷重 の力積を獲得したことが分かる.また, TypeA と TypeC を比較した結果, TypeB と同様に, クリーツ高を低下 させた $i=12$ の周辺に位置する $i=13,15,16$ の值が増加す
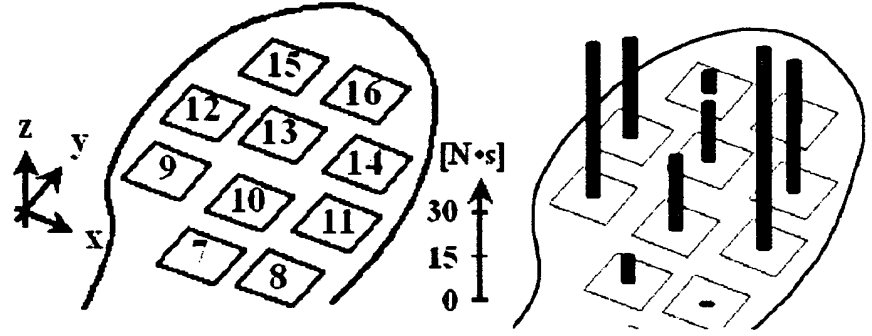

Type A

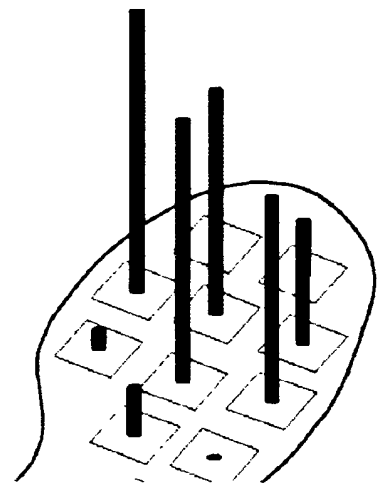

Type B

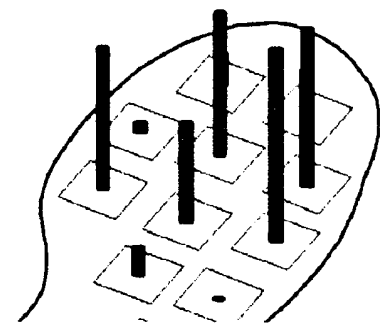

Type C
Fig.7 Comparison of Horizontal impulses under wearing
ることが分かった。

以上の結果から，局所的にクリーツ高を変化させる ことで，シューズと路面との接地状態を変化させ, ク リーツが負担する水平方向荷重分布が変化することが 確認された. 本手法により, クリーツ高の変化やクリ 一ツ配置とクリーツ単体に作用する 3 方向荷重との関 係を明らかにすることで，より精度の高いサッカース パイクのグリップ性設計の実現が期待される.

\section{4. 結言}

グリップ性を考慮したクリーツの設計指針を構筑す べく, ステップ幅を変化させた際の, 地面反力, 及び 接地エリア内の荷重分布を明らかにした. 更にクリー ツ高さを変化させることで局所的にグリップ性を変化 させた時の近接するクリーツへの影響,及びステップ 幅変化について述べた。 得られた，知見を以下に述べ る.

（1）ステップ幅の增加と共に, 水平方向地面反力の $1 \mathrm{st}$ ピーク值，2nd ピーク值ならびに支持期全体の力 積值共に，增加することを確認した．ステップ幅 の增加に従い，体勢を維持するためにグリップ力 が必要になったためであると推察される.

(2) クリーツ高さの局所的な减少は, 周囲のクリーツ に対して，負荷が増大寸ることや，接地のタイミ ングを早めるといった影響を与える事が分かった，

(3) 局所的にクリーツ高を変化させることで，シュー ズと路面との接地状態を変化させ, クリーツが負 担する水平方向荷重分布が変化することが確認さ れた.

\section{5. 参考文献}

1) Sterzing, $T$.,Actural and perceived running performance in soccer shoes, Footwear science (2009), 1(1):5-17

2) Stefanyshy,D.The influence of soccer cleat design on resultant joint moment ,Footwear science (2010),2(1):13-19 3) Edward M, Development of three axis spike force sensor and design of an asymmetric golf shoe outer sole , Footwear science(2011),3(S1):117-120

4) Kenta Moriyasu and Tsuyoshi Nishiwaki, Footwear science (2009), 1(1): 109-111

5) 森安健太,西脇剛史,日本機会学会 (No.09-45) シンポ ジウム講演論文集（2009）,277-280 